DOI : 10.5050/KSNVE.2010.20.10.931

$$
\begin{gathered}
\text { 자동차 대시 구조의 소음진동 성능개선을 위한 } \\
\text { 단순 상사구조물의 소음방사성능 연구 }
\end{gathered}
$$

\title{
Study on Acoustical Radiation from Simplified Systems of a Dash Structure for NVH Performance
}

\author{
임 차 섭*.유 지 우†.박 철 민**.조 진 호*** \\ Cha-Sub Lim, Ji Woo Yoo, Chul Min Park and Jin Ho Jo \\ (2010년 7월 22일 접수 ; 2010년 10월 4일 심사완료)
}

Key Words : Dash Panel(대시 패널), Radiation Efficiency(방사효율), Radiation Power(방사파워), Damping Sheet(제진재), Sound Package(흡차음재), Transmission Loss(TL, 전달손실)

\begin{abstract}
A dash panel plays an important role to protect noise as well as heat. Meanwhile, it is also the most important path that transfers energy to the interior cavity, so that some of noises are transferred via air and its structural vibration becomes a major issue. From the viewpoint of NVH performance, simplified structures analogues to the dash wall are dealt with. Stiffeners, damping sheets and sound packages attached to a flat panel are taken into account as design variables. Structural radiation characteristics(thus, structure borne) such as radiation efficiency and radiation power are mainly discussed. For the case when an excitation is applied on a frame that surrounds the panel, it is shown that the radiation efficiency increases by attaching a stiffener to the panel, which is similarly found from the case when a panel is directly excited. It seems more effective to attach damping sheets along the boundary area of the panel rather than its middle area. The radiation efficiency of sound packages may make a dominant contribution to transmission loss as well as sound radiation. Experimental work was carried out to verify the results based on the simulation study.
\end{abstract}

\section{1. 서 론}

차량의 대시 부위(dash component)는 승객과 가 장 인접하여, 차량의 주요 소음원인 엔진으로부터의 소음과 열을 차단하는 중요한 기능을 한다. 대시 인 슐레이터(insulator), 대시 패드(dash isolation pad) 등 은 이러한 기능의 주요한 역할을 하는 흡차음재로

$\uparrow$ 교신저자; 정회원, 현대기아자동차 해석기술팀

E-mail : j.w.yoo@hyundai-motor.com

Tel : (02)3464-7676

* 현대자동차 기능시험1팀

** 현대자동차 해석기술팀

***NVH Korea(주) 시험평가팀
특히 소음전달을 최소화하는데 중요하다. 동시에 대 시 부위는 에너지가 실내로 전달되는 경로상에 위치 하여, 소음의 일부가 공기기인으로 실내로 전달되고, 엔진룸의 부재와 연결되어 구조가진을 일으킨다. 따 라서, 차량 $\mathrm{NVH}$ (noise, vibration and harshness) 성능 개발을 위해, 구조와 흡차음재를 최적화하여 적용하 는 것이 중요하나, 레이아웃 결정 이전단계에서 성 능특성을 반영하여 설계에 적용하기 위한 개념적인 연구가 부족하여, 설계후반기에 성능만회를 위한 비 용과 시간이 소모되고 있다.

이 연구는 이러한 관점에서 대시 부위의 상사구조 인 단순구조물을 대상으로 하여 성능개발에 필요한 
설계개념을 제시하고자 하였다. 특히, 보강부재 (stiffener), 제진재(damping sheet), 흡차음재(sound package) 등의 주요 설계 인자가 중고주파수 $(100 \sim 1200 \mathrm{~Hz})$ 대역에서의 구조적인 소음방사특성 (방사파워, 방사효율)에 미치는 영향을 해석 및 시 험을 통해 검토하였다.

해석은 $\mathrm{FE}, \mathrm{SEA}$ 해석 및 이들의 통합해석이 가 능한 $\mathrm{VA} \mathrm{One}{ }^{(1)}$ 을 이용했고, 시험은 반무향실 및 잔향실에서 진행되었다.

이 논문에서 가장 중요하게 검토될 방사파워와 방사효율에 대해, 주로 단순 구조물-단순지지 평판 등-에 대한 연구가 진행된 바 있다. Kamura 등은 평판 위의 특정위치 가진 시, 제진재 부착 여부에 관계없이 bead가 추가된 평판의 방사효율 및 방사 파워가 높음을 보였으며(2), Kato 등은 역시 bead 높이가 클수록 1 차 공진모드 주파수는 상승하지만 방사효율이 크며, 복곡판(curved panel) 등에 대해 언급하였다 ${ }^{(3)}$. Glandier 등은 방사모델을 $\mathrm{FE}$ 로 구성 함에 있어, 구조(structure)가 소음 방사특성에 가장 영향이 큰 부위이며, 구조물에 장착된 트림 부위는 영향이 적음을 보였다 ${ }^{(4)}$. 모든 주파수 대역에 대한 소음방사특성에 대한 연구가 Xie 등에 의해 이루어 졌다. 단순지지된 평판을 대상으로 저주파 공진진동 수(fundamental frequency)와 고주파 임계주파수 (critical frequency) 사이 대역에서 방사특성은 소위 corner, edge mode의 영역으로 경계부위의 길이가 길 수록 방사특성이 불리해 지는 것으로 알려져 있다 ${ }^{(5)}$. Maidanik은 임계주파수보다 충분히 낮은 주파수에 서, 단순지지조건에 비해, 근접장에 영향을 주는 클 램프조건에서 방사소음이 두 배가 된다고 하였다 ${ }^{(6)}$. 사각평판 슬라이딩 경계조건의 경우, 임계주파수

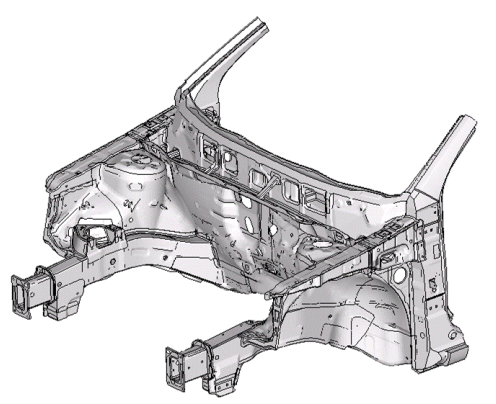

Fig. 1 Conventional configuration of a dash fire wall of an automotive vehicle
아래에서는 방사특성이 강체모드의 영향을 받는 것 으로 알려져 있다 ${ }^{(7)}$.

위에서 언급된 연구들은 대부분 단순구조 혹은 단순평판(bare panel)을 직접 가진한 경우였다. 그러 나, 대시 구조물은 Fig. 1과 같이 평판이 프레임에 장착되어 프레임이 구조적으로 가진되는 구조이다. 따라서 이와 유사하게 프레임에 의해 연결된 구조 에 대한 물리적인 특성을 확인할 필요가 있다.

이 논문에서는 특히 기존에 연구가 부족했던 흡 차음재와 방사효율, 전달손실 관계가 시험과 해석을 통하여 검토되었으며, 제진재가 방사특성관점에서 어떻게 기여하는지도 간략하게 검토되었다.

\section{2. 본 론}

\section{1 방사파워와 방사효율}

구조물의 진동에 의해 소음이 유발될 때, 방사 파워(radiation power), 방사효율(radiation efficiency), 구조물의 진동속도의 관계는 식 (1)과 같다 ${ }^{(5)}$.

$$
W=\rho c S\left\langle\overline{v^{2}}\right\rangle \sigma
$$

여기서, $W$ 는 방사파워(Watt), $\rho$ 는 공기밀도, $c$ 는 음속, $S$ 는 면적, $v$ 는 구조물(평판)의 진동속도, $\sigma$ 는 방사효율(radiation efficiency)이다. 이 식에서 알 수 있듯이 방사파워는 방사효율이나, 진동량에 비례 하는 것을 알 수 있다. 따라서 구조물에서의 방사특 성을 검토함에 있어 방사파워, 방사효율 모두가 중 요한 고려대상임을 알 수 있으며, 다음에서 이 두가 지 물리적개념이 주로 분석대상으로 검토되었다.

\section{2 모델 구성}

서론에서 검토된 바와 같이, 이전에 연구된 단순 평판의 경우, 주로 평판에 직접 가진한 예가 많았 다. 이 경우, 만약 일반적인 가진기법인 힘센서 등 을 사용하여 가진할 경우, 평판의 두께 $(0.8 \mathrm{~mm})$ 가 매우 얇기 때문에 고주파로 갈수록 센서중량의 영 향이 커지게 되어, 예를 들면 $440 \mathrm{~Hz}$ 이상에서 센 서중량 $20 \mathrm{~g}$ 에 의한 임피던스가 평판의 그것보다 커지게 된다. 이 경우 Fig. 2와 같이 중량 유무에 따라 방사파워의 차이가 있음을 알 수 있다. 또 다 른 중요한 점은, 실제 차량가진이 프레임을 통하여 
이루어진다는 점에서, 가진된 프레임을 통하여 평판, 공기로 순차적으로 에너지가 전달되는 구조가 좀 더 실차와 유사하다는 것이다.

이런 관점에서 대시 실차구조의 상사구조물로 Fig. 3과 같은 구조물을 고려하였다 ${ }^{(4)}$. 평판과 프레 임 모두 스틸재질이며, 평판 $(570 \mathrm{~mm} \times 450 \mathrm{~mm})$ 의 기본두께는 $0.8 \mathrm{~mm}$ 이다. 소음을 야기하는 판이 체 결부를 통하여 프레임에 고정되어 있으며, 이는 프 레임 꼭지점에서 가진기로 가진된다. 가속도센서 (Fig. 3 상단 우측)는 저주파모드를 분석하기 위해서 만 사용하였고, 고주파수에서의 영향이 없도록 방사 파워 측정시에는 제거하였다. 가진기에 의한 소음영 향을 배제하기 위해, 가진기 주위는 흡음재와 격벽 으로 차폐되었으며, 표면 인텐시티 스캔닝으로 경계 부위에서 leakage의 영향이 무시할 만 함을 확인하 였다.

해석모델은 FE와 SIF(semi-infinite fluid)요소로 구성된다. 해석 및 시험의 관심주파수는 $1.2 \mathrm{kHz}$ 이 하이다. 이는 차량소음 중 구조기인의 영향도가 큰 부분에 해당한다.

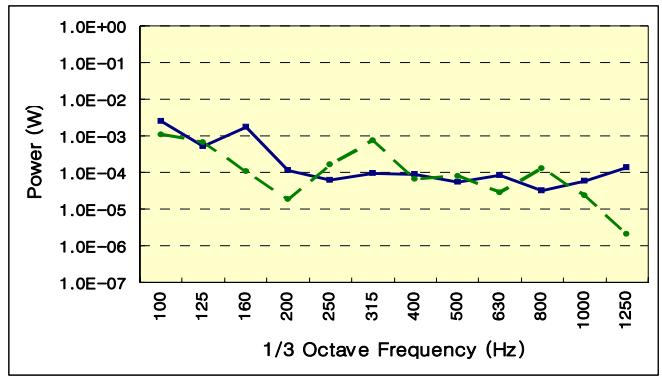

Fig. 2 Sound power radiated from a bare panel when the mass of a force sensor is considered or not(solid, no mass; dashed, $20 \mathrm{~g}$ of mass added)

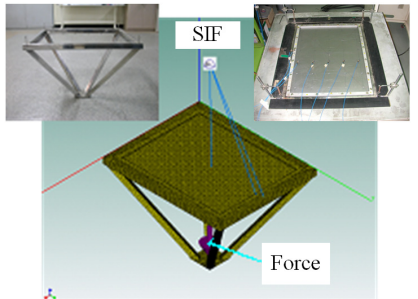

Fig. 3 Configuration of the framed panel to investigate sound radiation characteristics
$\mathrm{FE}$ 모델에 의한 구해진 대표적인 모드를 Fig. 4 에 보였다. 저주파에서는 판전체가 동일한 위상으로 거동하여 공기를 가진하는데 반해, 고주파로 갈수록 파장이 짧아져 많은 가진원이 나타나며, 이들은 인 접하는 반대위상의 거동에 의해 서로 상쇄되어 실 질적인 공기가진이 잘 안되는 현상이 나타난다. 따 라서, 공기가진은 주로 경계부위의 영향도가 커지는 것으로 알려져 있다 ${ }^{(5,6)}$. 공기가진의 특성은 이와 같 이 주파수대역에 따라 다른 양상을 가지며, 고주파 로 갈수록 모드가 많아지므로 고주파에서는 특정한 모드의 제어보다는 평균적인 개념에서 소음방사를 제어하는 방법이 필요하다.

평판에 의한 방사파워를 검토함에 있어서 특히 주의할 점은, 평판 외에 평판이 지지된 프레임 상단 표면(frame upper surface, 이하 프레임)에서의 소음 방사량이 포함된다는 점이다. 약 $600 ~ 800 \mathrm{~Hz}$ 이하 대역에서는 평판의 기여도가 훨씬 크지만, 주파수가 높아질수록 프레임의 기여도도 무시할 수 없는 수준 이 된다. 따라서, 프레임이 포함된 방사파워를 시험 해석간 우선 비교하였다, 이 연구의 목적은 평판만의 방사특성을 검토하는 것이지만, 시험의 경우 평판과 프레임의 기여를 명확히 분리해 내기 어려우므로,
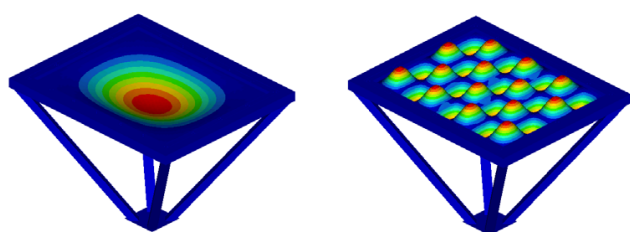

Fig. 4 Examples of normal modes calculated from the FE model $(28.9 \mathrm{~Hz}, 495 \mathrm{~Hz})$

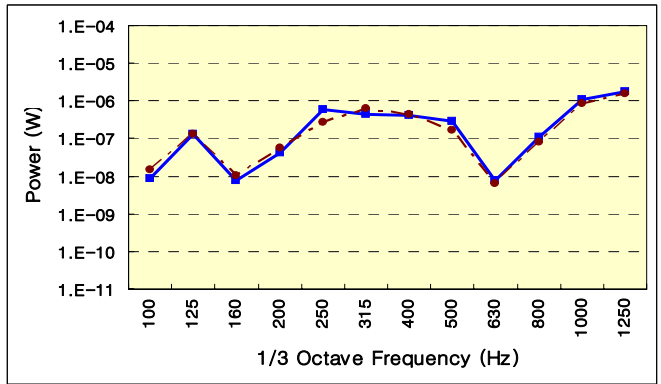

Fig. 5 Sound radiation power of the panel and frame upper surface(bare panel 0.8t. Solid, simulation; dot-dashed, test) 
평판만의 방사파워와 방사효율은 해석적으로 추출 하는 것이 효율적인 방법이 될 것이다. 이를 위한 필요조건은 평판과 프레임에 의한 방사파워가 시험해석간 일치하는 것이다.

소음방사파워(평판과 프레임 부위 방사파워)가 Fig. 5와 같이 시험-해석간 매우 잘 일치하는 것을 확인하였다. 이제 해석모델에서의 결과로부터 프레 임부위를 제외한 평판의 방사효율을 계산하는 것은 식 (1)로부터 가능하다.

\section{3 구조변경에 의한 음향방사 특성}

앞 절에서 언급된 바와 같이 저주파 방사 특성이 모드의 지배를 받으므로, 보강부재 장착에 의한 저 주파대역 고유진동수 변경으로, 특정 주파수에서의 방사파워를 조절할 수 있을 것으로 보인다. Fig. 6과 같이 +형 보강재(stiffener. 두께 $0.8 \mathrm{~mm}$, 폭 30.0 $\mathrm{mm}$, 높이 $14.0 \mathrm{~mm}$ )를 용접으로 장착한 경우에 대 해 방사소음 특성을 비교하였다. 프레임 자체 거동 이 주는 영향을 최소화하기 위해 보강재는 프레임 에는 직접적으로 연결되지 않았다.
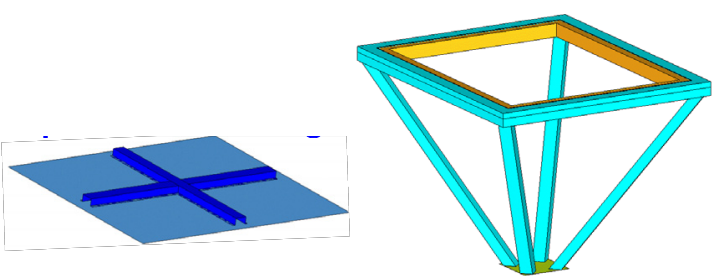

Fig. 6 Configuration of the stiffener-attached panel and frame

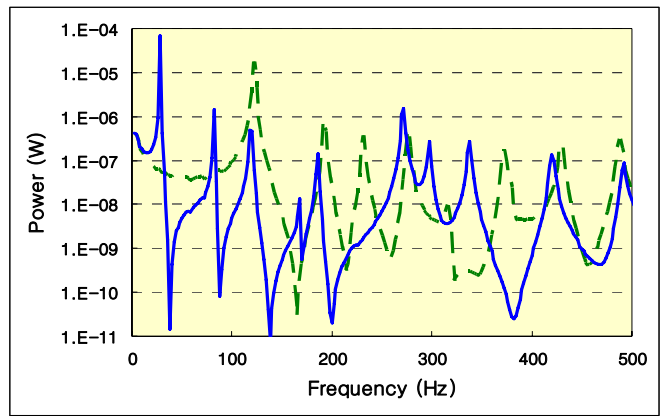

Fig. 7 Radiation power from the stiffener-attached panel(simulation result, power from only panel without frame. Solid, bare panel; dashed, stiffener-attached)

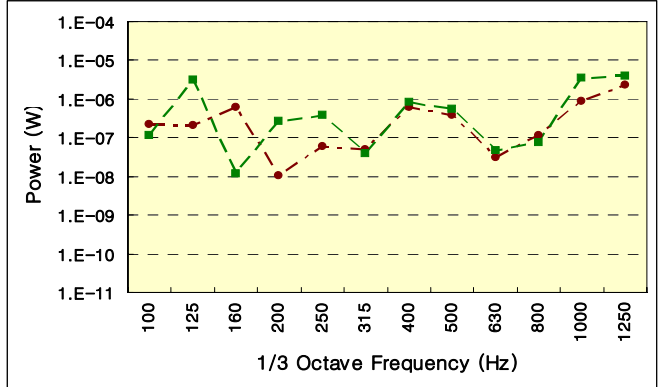

Fig. 8 Radiation power from the stiffener-attached panel and frame(dashed, simulation; dot-dashed, test)
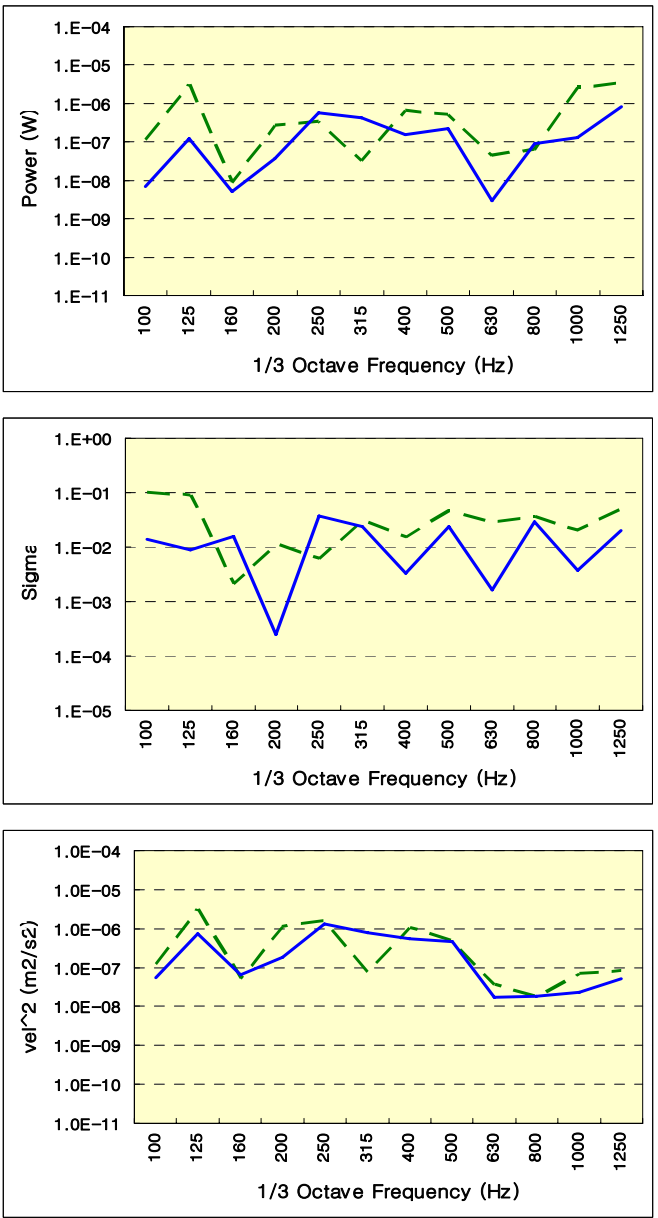

Fig. 9 Radiation power(upper), radiation efficiency (middle) and averaged square velocity(lower) of the bare panel and the stiffener-attached panel(simulation result, power from only panel without frame. Solid, bare panel; dashed, stiffener-attached panel) 
약 $400 \mathrm{~Hz}$ 까지의 저주파 대역에서는 보강재 장착 에 따라 방사 파워 특성이 분명하게 바뀌며, 평판 모드의 영향을 받는 것을 확인할 수 있다(Fig. 7).

한편, 고주파수 대역에서 방사파워를 시험-해석간 비교하면(Fig. 8), $315 \mathrm{~Hz}$ 이상에서 잘 일치하는 것 을 알 수 있다. 저주파 대역의 차이는 보강재 장착 시의 시험시편의 용접불량이 원인이 된 것을 확인 하였다.

시험비교로 각 모델의 타당성이 증명되었으므로, 이제 평판부위만의 방사파워와 방사효율을 보면, 보 강재 추가시의 방사특성 변화를 확인할 수 있다.

Fig. 9에서와 같이 $400 \mathrm{~Hz}$ 이상에서 보강재가 장 착된 경우 방사파워와 효율이 모두 커지는 것을 알 수 있다. 평판의 평균속도(Fig.9의 하단) 차이에 비 해, 방사파워의 차이가 커진 것을 알 수 있으며, 보 강재 추가로 평판과 보강재의 경계선 길이가 약 90 $\%$ 길어지므로써, 방사효율이 커진 것을 알 수 있다 (Fig. 9의 중앙). 따라서 평판을 직접 가진한 경우와 유사하게 ${ }^{(5,6)}$, 프레임부위가 가진되는 경우에도 평판 과 프레임의 경계부위가 소음방사에 크게 기여함을 알 수 있다.

\section{4 제진재 부착에 의한 소음방사 특성}

구조진동에 의한 소음발생 영역에서 제진재의 역 할은 매우 중요한 것으로 알려져 있다. 그러나, 최 적의 설계위치에 대한 일반적인 가이드는 알려져 있지 않다.

보강재가 장착된 평판 면 위에, Fig. 10과 같이, 경계부위와 면의 가운데 부위에 각각 제진재가 부 착되는 2 가지 경우에 대해 방사성능을 비교 검토하 였다. 적용된 제진재의 면적(방사면적의 $40 \%$ 적용) 은 동일하며, $1.5 \mathrm{t}$ 아스팔트 제진재를 사용하였다.

Fig. 11에서 볼 수 있듯이, 부착하지 않은 경우에 비해, 제진재를 부착하는 경우, 방사파워 저감의 효 과가 있는 것을 알 수 있다. 이것은 제진재를 부착 하므로써, 평판의 진동이 부착위치에 무관하게 크게

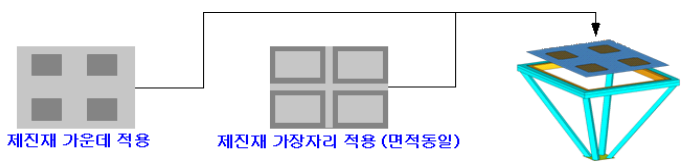

Fig. 10 Configurations for attachment of damping sheets(dark grey for damping sheets)
감소하기 때문이다. 한편, 시험-해석간 차이는 방사 파워에 프레임의 기여가 포함되지 않았기 때문이다.

제진재 부착위치에 따른 방사효율을 Fig. 12에 비 교하였으며, 제진재를 평판의 경계부위에 장착하는 것이 유리함을 알 수 있다.

특정모드의 영향이 지배적인 저주파의 경우 변형 에너지가 집중되는 부위에 제진재를 붙이는 것이
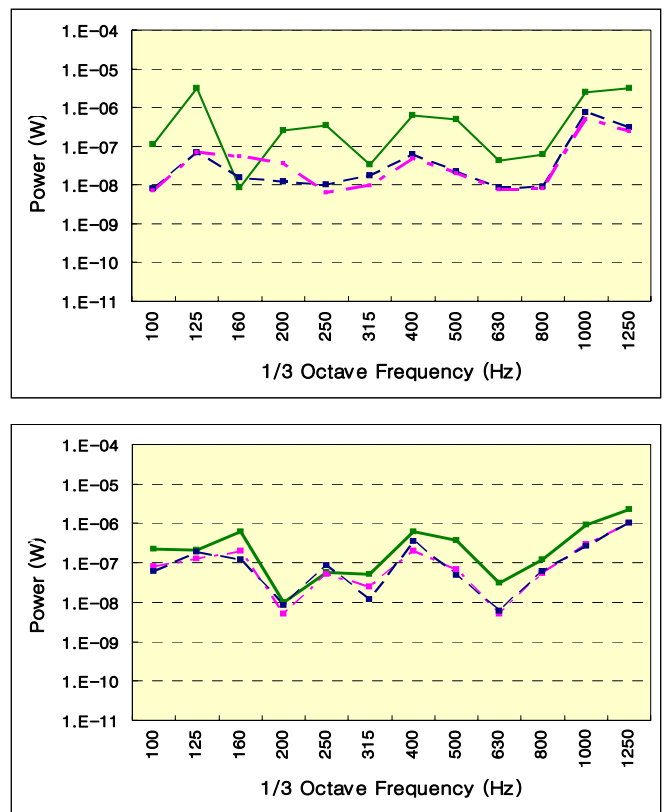

Fig. 11 Radiation power when damping sheets attached(upper, simulation; lower, test. Solid, no damping sheets; dashed, damping sheets at mid-area; dot-dashed, damping sheets at boundary area)

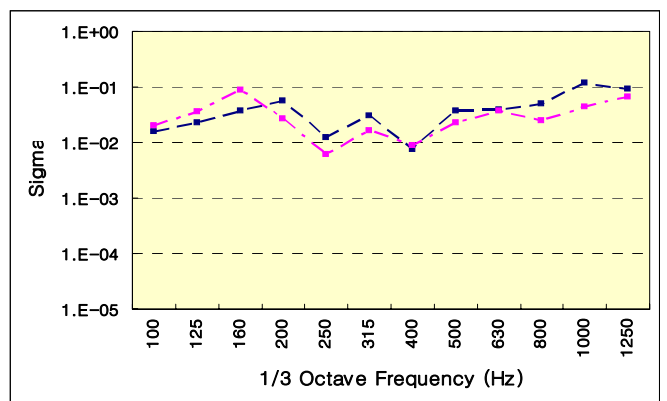

Fig. 12 Radiation efficiency when damping sheets attached(simulation results. Dashed, damping sheets at mid-area; dot-dashed, damping sheets at boundary area) 
유리한 것은 알려진 사실이다. 그러나, 고주파 대역 에서는(예. Fig. 4의 $495 \mathrm{~Hz}$ 모드의 경우) 소음방사 가 주로 경계부위에서 발생하므로 제진재를 장착하 므로써, 이 부위에서 생기는 근접장의 영향을 완화 할 수 있기 때문에 소음특성면에서 유리한 것으로 추정된다 ${ }^{(6,8)}$. 관련하여, 명확한 원인규명을 위해서 추가적인 연구가 필요할 것으로 판단된다.

\section{5 흡차음재 부착에 의한 음향방사특성}

흡차음재(sound package)는 주로 $1 \mathrm{kHz}$ 이상의 고 주파수 대역의 공기기인 성능에 가장 중요한 역할 을 하고 있다. 흡차음재는 보통 9개의 물성치 (유동 저항, 뒤틀림률, 공극률, 열특성길이, 점성특성길이,

Table 1 Layer combination of sound packages

\begin{tabular}{c|c|c}
\hline \hline Layer case & Layer & Index \\
\hline Baseline & Bare panel & ------ \\
\hline Case A & Panel + PET X + EVA & ------ \\
\hline Case B & $\begin{array}{r}\text { Panel + PET X +Film } \\
+ \text { PET Y }\end{array}$ & ---- \\
\hline Case C & Panel + PU + Film + PET Y & ---- \\
\hline Case D & $\begin{array}{r}\text { Panel + EcoFELT X } \\
+ \text { EcoFELT Y }\end{array}$ & ---- \\
\hline Case E & Panel + PET X & ---- \\
\hline
\end{tabular}
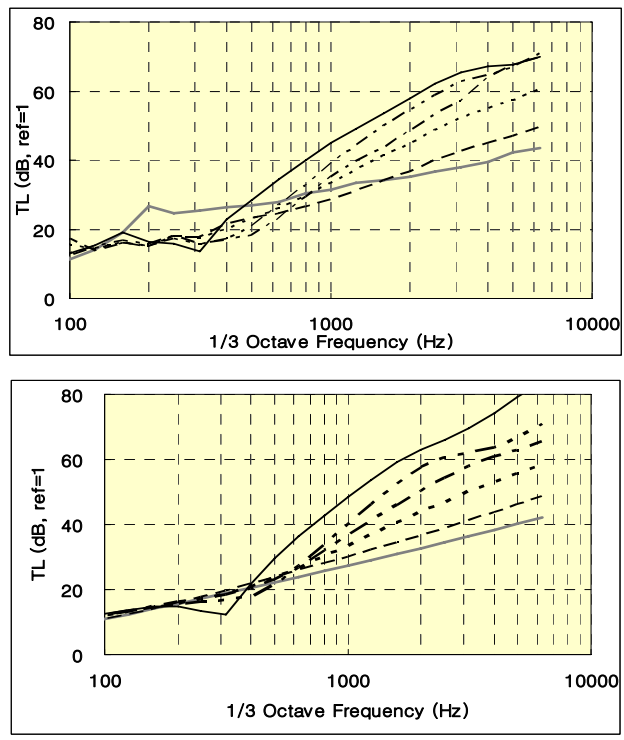

Fig. 13 Transmission loss of sound packages(5 representative layers. Upper, test; lower, simulation. Cases as explained in Table 1)
체적밀도, 탄성계수, 푸아송 비, 손실계수)로 모델링 된다. 일반적인 모델링은 재질에 따라 다소 다른데, bulk modulus가 매우 적은 것으로 알려진 PET (poly-ethylene) 계열은 고체특성 즉 탄성계수, 푸아 송 비, 손실계수를 일반적으로 반영하지 않는 반면, foam 계열(예. poly-urethane, PU)은 이들도 포함하 여 모델링하는 것으로 알려져 있다 ${ }^{(9)}$.

주요 흡차음부품에 대해(Table 1 참조. mass density $\mathrm{Y}=0.8 \times \mathrm{X} \mathrm{g} / \mathrm{m}^{2}, \mathrm{X}$ 는 특정 mass density를 의미) 전달손실(transmission loss, TL)을 시험하여, 해석모델과 비교하였으며, 그 결과로부터, PET 계 열의 부품도 일정한 강성값을 가지고 있는 것으로 판단되며, 관련된 3 개 항을 포함하여 모델링 한 경 우, Fig. 13 과 같이 전달손실의 해석치가 시험치를 더 근사하게 묘사하는 것을 확인할 수 있었다. 이는 기존 연구(9)에서도 언급된 바 있다.

Fig. 14와 같은 개념도로 대표되는 흡차음재가 장 착된 구조물에 대해, 위에서 구해진 전달손실과 음 향방사특성의 관계에 대해 검토한다.

음향가진에 의한 전달손실 성능은 구조가진에 의 한 전달손실과 같은 방법(참고문헌 (10)의 식 (10)) 과 같이, 식 (2)와 (1)로부터 유도할 수 있다.

$$
W=\operatorname{Re} \int\left\langle p_{2} \cdot u_{2}\right\rangle d s=\rho c \sigma\left\langle v_{1}^{2}\right\rangle S
$$

여기서, $p_{2}$ 는 방사음의 음압, $u_{2}$ 는 방사음의 입자속 도, $v_{1}$ 은 평판의 진동속도, $\sigma$ 는 평판에 흡차음재가 장착된 경우의 방사효율이다.

이 식으로부터 흡차음재의 방사효율 $\sigma$ 를 가지는 전달손실은 다음과 같이 계산할 수 있다.

$$
\begin{aligned}
& \tau=\frac{W_{t}}{W_{i}}=\frac{\operatorname{Re} \int\left\langle p_{2} \cdot u_{2}\right\rangle d s}{\frac{\left\langle p_{1}^{2}\right\rangle S}{4 \rho c}}=\frac{\rho c \sigma\left\langle v_{1}^{2}\right\rangle S}{\frac{\left\langle p_{1}^{2}\right\rangle S}{4 \rho c}} \\
& =4 \rho^{2} c^{2} \sigma \frac{\left\langle v_{1}^{2}\right\rangle}{\left\langle p_{1}^{2}\right\rangle} \\
& T L=10 \log 10(1 / \tau)
\end{aligned}
$$

여기서, $p_{1}$ 은 입사음의 음압, $\tau$ 는 에너지전달계수 (transmission coefficient), $T L$ 은 전달손실이다.

흡차음재를 장착하면서 생기는 가진 음장부의 음압 
$\left\langle p_{1}^{2}\right\rangle$ 의 변화량과 평판 진동속도 $\left\langle v_{1}^{2}\right\rangle$ 의 변화량이 적다면, 전달손실 성능은 흡차음재의 방사효율에 직 접적인 영향을 받는다는 것을 알 수 있다. 따라서, Fig. 13에서 구해진 전달손실 성능곡선은, 가진면 평 판의 거동특성이 유사하다면, 해당 흡차음재의 방사 효율 곡선과 같은 경향을 가지며, 이 영향은 구조가 진의 경우에도 동일한 영향을 줄 것으로 기대된다.

구조가진시, 흡차음재의 음향방사특성을 검토하기 위해, Fig. 15에서와 같이 시험장비를 이용, 방사파 워를 측정하였다. 평판이외의 프레임부위의 영향을 최소화하기 위해, 두께 $25 \mathrm{~mm}$ 의 흡음재로 외부를 덮었다. 해석모델은 Fig. 13에서 구해진 흡차음재 모델을 앞의 Fig. 3에 보인 구조모델의 평판에 연성 시켜 계산하였으며, 프레임부위는 시험에서 사용된 흡음재 특성을 반영하였다.

시험 및 해석결과는 Fig. 16과 같다(대표적인 2가 지 case $\mathrm{A}, \mathrm{C}$ 에 대해 도시하였다). 평판+PET+EVA 의 경우 레벨은 유사하나, 약간의 피크 천이가 있으 며(상단), 평판+PU+Film+PET의 경우는 시험과 매 우 잘 일치한다(하단).

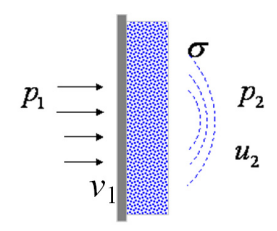

Fig. 14 Configuration of the panel with sound packages installed in a window between a reverberant room and an anechoic room

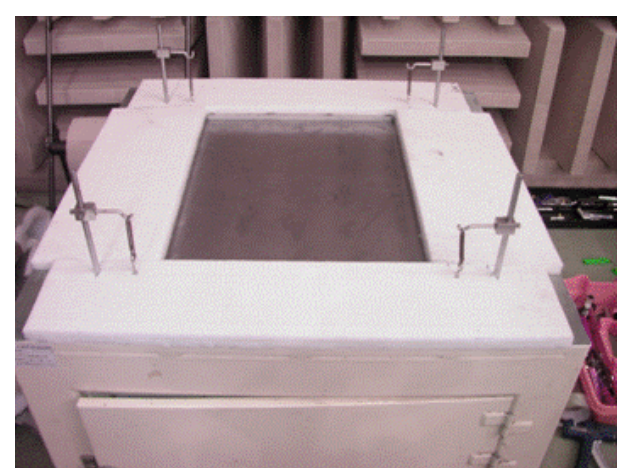

Fig. 15 An experimental setup to measure radiation power when sound packages are placed on the panel
Fig. 16의 결과와 앞의 Fig. 13 의 결과에서 방사효 율은 동일하며, Fig. 17에 방사효율을 도시하였다. 따라서, 방사효율은 전달손실과 소음방사에 동일한 기여를 하는 것을 알 수 있다.

앞에서, PET 재질에 대해 탄성을 고려했음을 밝 힌 바 있다. 그런데, 공기가진에 의한 전달손실 시 험시의 시편은 수직에 가까운 평판에 장착되는 반 면, Fig. 15 와 같이 장착되는 경우, 평판과 비교적
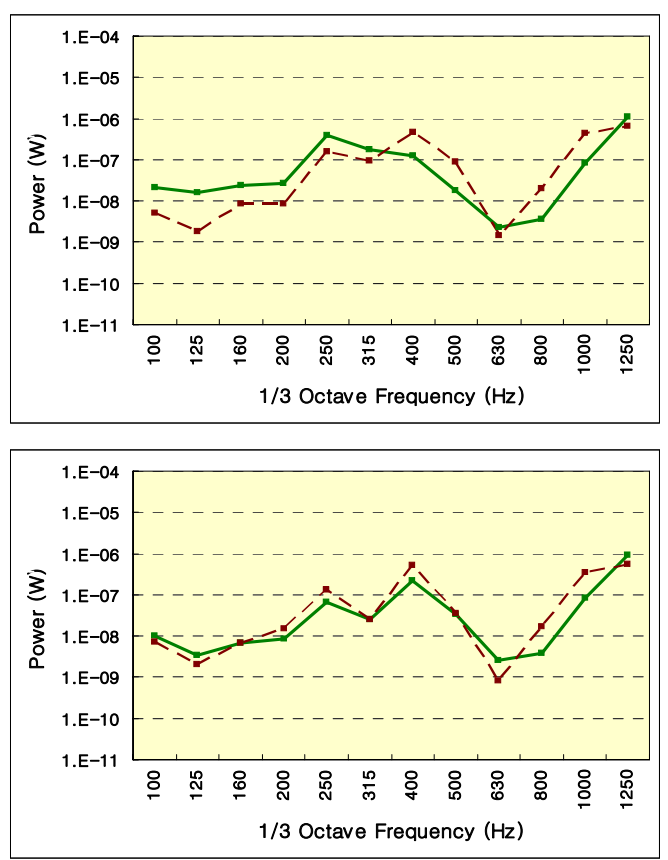

Fig. 16 Radiation power when sound packages attached(upper, panel+PET+EVA; lower, panel+PU+Film+PET. Solid, simulation; dashed, test)

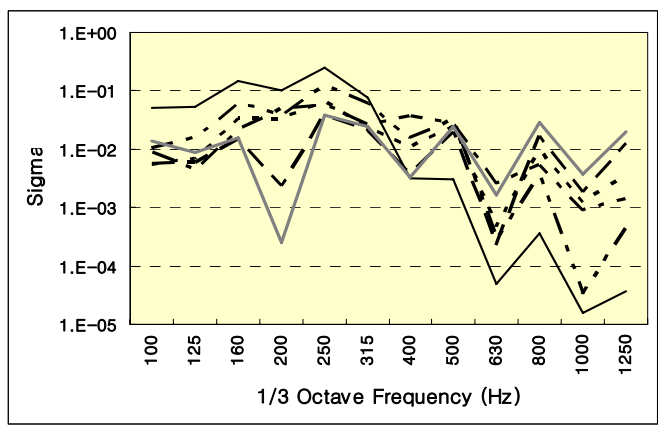

Fig. 17 Radiation efficiency of sound package coupled to the panel(cases explained as in Table 1) 


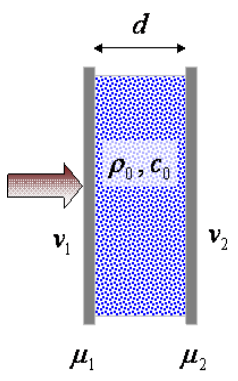

Fig. 18 Configuration of sound package coupled to the panel(panel-PET-EVA)

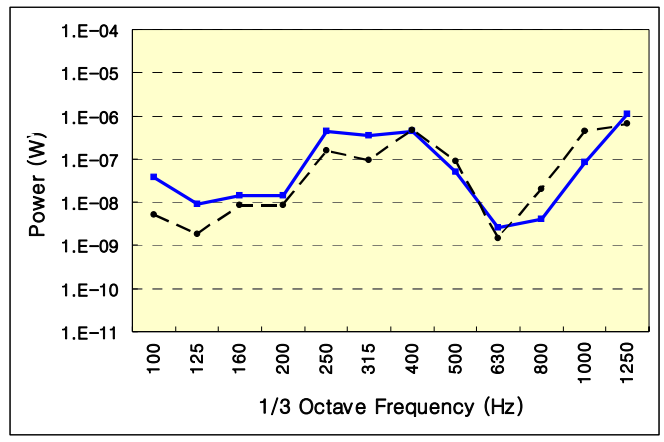

Fig. 19 Radiation power when sound packages attached(panel+PET+EVA. Solid, simulation; dashed, test)

단단하고 무거운 $\mathrm{EVA}$ 사이에 위치한 $\mathrm{PET}$ 는, 자중 및 장착조건에 의해 그 실제 탄성값이 최초의 그것 과 차이가 있다. 즉, Fig. 18과 같이 구조가진이 이 루어 질 때, 평판-PET-EVA의 동적 거동은 다음 식 (5)와 같이 거리 $d$ 의 영향을 받게 되며, 이 값은 자 중 및 장착조건에 따라 실질적인 값이 달라질 것으 로 추정된다.

$$
\omega_{0}^{2}=\frac{\kappa_{0}}{d} \frac{\mu_{1}+\mu_{2}}{\mu_{1} \mu_{2}}=\frac{\rho_{0} c_{0}^{2}}{d} \frac{\mu_{1}+\mu_{2}}{\mu_{1} \mu_{2}}
$$

여기서, $\omega_{0}$ 는 고유진동수, $d$ 는 평판과 $\mathrm{EVA}$ 간의 거리, $\mu_{1}, \mu_{2}$ 는 각각 해당 면밀도, $\kappa_{0}$ 는 공기의 bulk modulus 이다.

장착조건과 눌림량을 가정하여, 거리 $d$ 를 $5 \mathrm{~mm}$ 줄여서 적용하는 경우, 방사파워는 Fig. 19와 같이 변경되어, 시험결과와 더욱 유사한 것을 알 수 있 다. 따라서, 모델링시 이러한 영향을 고려하는 것이 타당한 가정임을 알 수 있다.

\section{3. 결 론}

차량의 대시 부위 소음 방사특성을 모사하기 위 해, 프레임 가진에 의한 평판의 소음방사특성을 주 요 설계변수 별로 검토하였으며, 다음과 같은 결론 을 얻을 수 있었다.

해석에 의한 음향특성예측이 시험과 잘 일치함을 알 수 있으며, 실차 문제의 예측을 위해 이 연구에 서 사용된 해석기법이 유용하게 활용될 수 있음을 보였다.

보강재에 의한 평판 보강 구조가 저주파에서는 고유진동수의 특성에 지배를 받는 반면, $400 \mathrm{~Hz}$ 이 상의 중고주파수 대역에서는 소음특성에 불리하게 작용함을 확인하였다. 이와 관련하여 특히, 방사효 율의 영향을 확인하였으며, 보강재에 의한 평판의 경계부위 증가가 방사효율을 크게 만드는 것을 확 인하였다. 이는 프레임가진시의 결과로서, 평판을 직접 가진하는 경우에 대한 기존 연구결과와 유사 하다.

제진재 부착이 방사파워를 줄이는데 효과적임을 확인하였다. 제진재 부착위치는 평판과 보강재가 연 결되는 경계부위가 보다 효과적인 것으로 보인다. 이렇게 함으로써 근접장의 영향을 완화할 수 있기 때문인 것으로 추정되나, 명확한 이유는 추가적인 연구가 필요하다.

기존 연구가 미흡했던 흡차음재 적용시의 소음방 사 특성에 대해 검토하였으며, 이를 전달손실 특성 과 비교하였다. 흡차음재 적용시, 전달손실계수와 소음방사특성은 동일한 방사효율로 설명이 가능하 며, 두 특성 모두 방사효율의 영향이 크게 작용함을 알 수 있었다.

방사파워의 저감에 있어서, 흡차음재와 제진재의 역할이 다름을 알 수 있다. 제진재는 구조의 진동을 직접 줄이지만, 흡차음재는 방사효율을 저감시킴으 로써 방사소음을 줄이는 것을 알 수 있었다.

\section{참 고 문 헌}

(1) VA One, User's Manual, 2010.

(2) Kamura, T., Utsunomiya, A., Sugihara, T. and Tobita, K., 1997, "Improvement of Road 
Noise by Reduction of Acoustic Radiation from Body Panels," JSAE9741126.

(3) Kato, T., Hoshi, K. and Umemura, E., 1999, "Application of Soap Film Geometry for Low Noise Floor Panels," SAE 1999-01-1799.

(4) Glandier, C. Y., Lehmann, R., Yamamoto, T. and Kamada, Y., 2005, "Vibro-acoustic FEA Modelling of Two-layer Trim Systems," SAE 2005-01-2325.

(5) Xie, G., Thompson, D. J. and Jones, C. J. C., 2005, "The Radiation Efficiency of Baffled Plates and Strips," Journal of Sound and Vibration, Vol. 280, pp. 181 209.

(6) Maidanik, G., 1962, "Response of Ribbed Panels to Reverberant Acoustic Fields," J. Acoust. Soc. Am., Vol. 34, pp. 809 826.

(7) Yoo, J. W., 2009, "Sound Radiation
Characteristics of Rectangular Plates with a Guided Edge Condition," Transactions of the Korean Society for Noise and Vibration Engineering, Vol. 19, No. 9, pp. 1598 2785.

(8) Tarnóczy, T., 1970, "Vibration of Metal Plates Covered with Vibration Damping Layers," Journal of Sound and Vibration, Vol. 11, pp. 299 $\sim 307$.

(9) Park, C. M., Chae, K. S., Yoo, J. W. and Kang, Y. J., 2010, “A Study on Material Properties of Porous Materials," Proceedings of the Acoustical Society of Korea Conference.

(10) Liu, B., Fenga, L. and Nilsson, A., 2007, "Sound Transmission Through Curved Aircraft Panels with Stringer and Ring Frame Attachments," Journal of Sound and Vibration, Vol. 300, pp. 949 973. 